Feature Article

\title{
Potential of Biomass Based Electricity Generation in Sri Lanka
}

\author{
K.P. Ariyadasa*
}

\begin{abstract}
Biomass has attracted much attention as a primary energy source for electricity generation due to its potential to supply low cost fuel source with considerable environmental and socio-economic benefits. Despite having favorable climatic conditions to grow and use biomass for electricity generation, biomass based electricity generation in Sri Lanka is lagging behind due to many reasons. Many countries rely on the agricultural or forestry by-products or residuals as the main source of biomass for electricity generation mainly due to the comparatively low cost and sustainable supply of these by-products. Sri Lanka does not have this advantage and has to rely mainly on purposely grown biomass for electricity generation. Development of short rotation energy plantations seems to be the best option available for Sri Lanka to produce biomass for commercial scale electricity generation. The highly favorable growing conditions, availability of promising tree species and a variety of plantation management options and significant environmental and socio-economic benefits associated with energy plantation development greatly favor this option. This paper examines the potential of using plantation grown biomass as a fuel source for electricity generation in Sri Lanka.
\end{abstract}

Keywords: biomass, energy plantations, electricity generation, Sri Lanka

\section{Introduction}

Biomass is a renewable resource comes primarily from plants and vegetation that naturally regrows. It mainly comes from agricultural and other industrial processes as a byproduct or residuals while purposely grown biomass for power generation is also available. In recent times, biomass has attracted much attention as a primary energy source for electricity generation due to its potential to supply low cost fuel source with considerable environmental benefits. Socio-economic benefits such as local employment generation, mitigation of adverse impacts of climate change and potential carbon trading benefits are among other advantages of using biomass as a fuel source for power generation. Coal may be the only fuel source cheaper than biomass but it is responsible for producing the most carbon emissions and other pollutants than any other fuel source.

Though biomass has the largest share of primary energy supply in Sri Lanka, which accounts for nearly $45 \%$ of the total energy supply, it is mainly used for cooking and heating and has very limited use for electricity generation. Despite having favorable conditions in Sri Lanka to grow and use biomass for electricity generation, biomass based electricity generation is lagging behind due to many reasons.

${ }^{*}$ Correspondence:

Tel: +94755600515

ISSN 2235-9370 Print/ISSN 2235-9362 Online @ University of Sri Jayewardenepura 


\section{Biomass Supply Chain}

Using biomass for commercial scale power generation is in its infancy in Sri Lanka. Suppliers and supply chains have not yet been developed and it is not clear at present how the biomass supply chain will or should develop. Forest based supply chain and agricultural supply chain are the two main supply chains that provide biomass required for power generations (Figure 1).

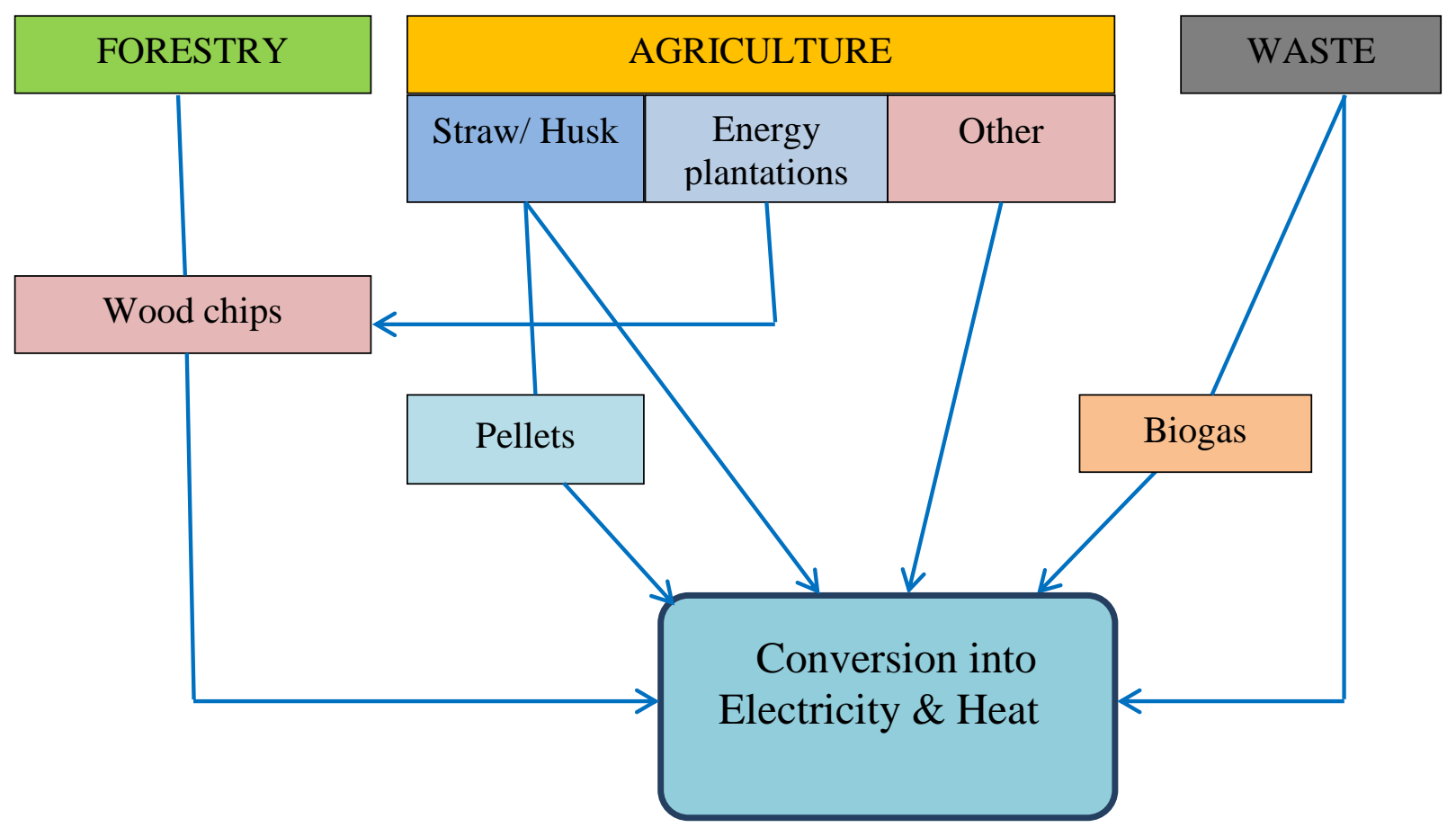

Figure 1: Biomass primary resources input into electricity and heat generation.

\subsection{Forest based supply chain}

Many countries rely on the forest based supply chain to obtain required biomass for power generation. Primary resources from natural forests and forest plantations are divided into four main categories (Figure 2).

- Logging residues including branches and non-commercial stem wood from logging of forests or forest plantations

- Stumps and root wood from clear cutting areas

- Round wood not suitable for industrial use

- Small diameter wood from thinning operations of forest plantations.

All natural forests in Sri Lanka are set apart for conservation and no logging is taking place since the logging ban imposed in 1990. Therefore, natural forests cannot be considered as a biomass source for power generation in Sri Lanka. There are about 85,000 ha of forest plantations in Sri Lanka and majority of these plantations are used to produce commercial timber. Annual production of the plantations is about $150,000 \mathrm{~m}^{3}$ and logging operations would generate about $35,000 \mathrm{~m}^{3}$ of residues annually. These logging residues are currently used mainly for fuel wood. Forest plantations also produce small diameter timber through thinning operations, especially during the pre-commercial 
thinning in young plantations. Since forest plantations in Sri Lanka produce comparatively small quantity of industrial wood, less than $10 \%$ of the national wood demand, the amount of logging residues generate through logging operations is also very small. As such Sri Lanka does not have a viable forest based supply chain to provide biomass for commercial power generation.

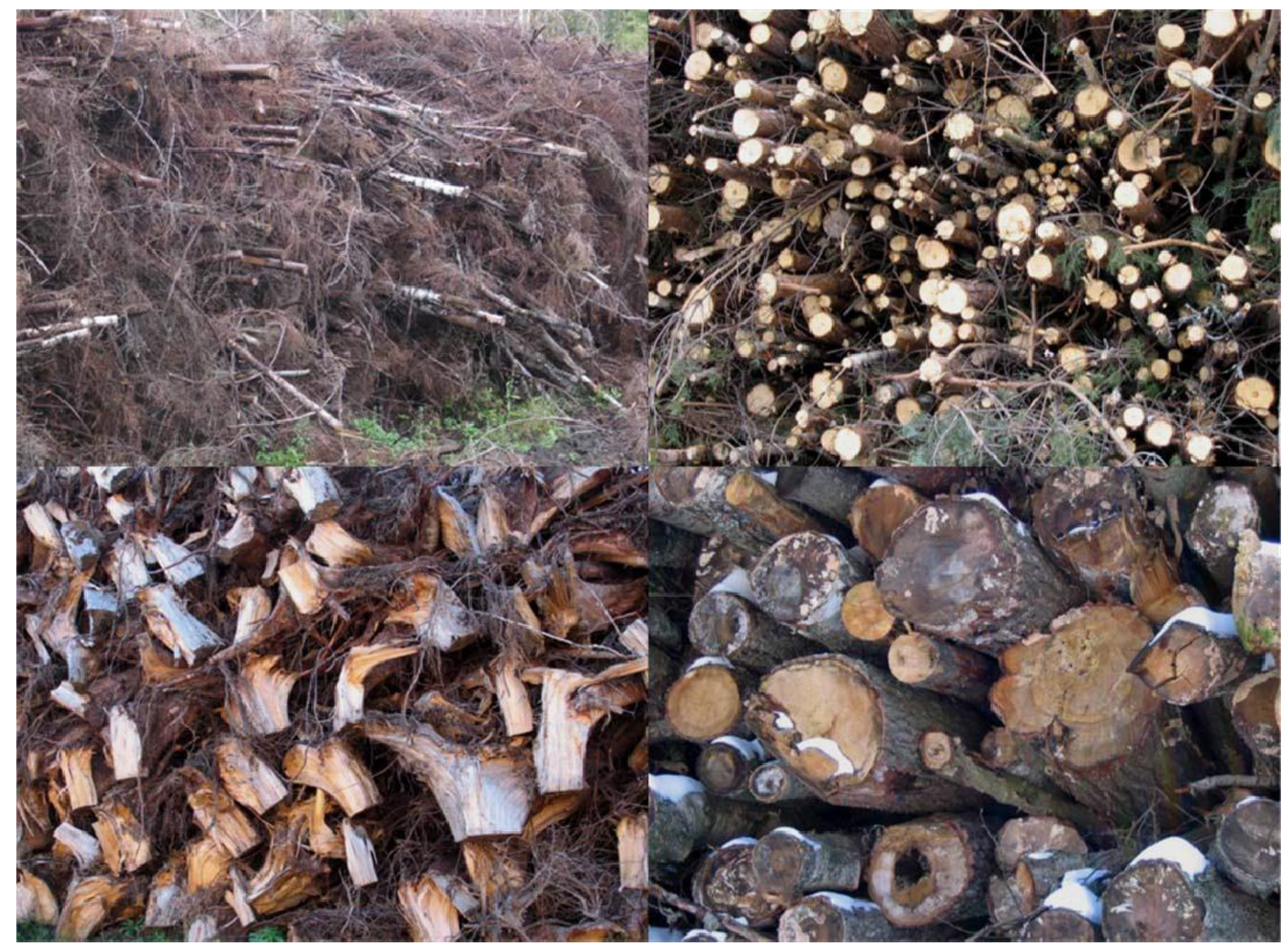

Figure 2: Primary biomass sources from forests.

Top left logging residues, top right small diameter thinning materials, bottom left stumps and bottom right non-commercial round wood.

\subsection{Agricultural supply chain}

Agricultural crop residues play the key role in supplying biomass for power generation in many countries. Agricultural supply chain consists of materials from agricultural harvesting and processing (such as rice straw, paddy husk and coconut shells) and other industrial byproducts such as bagasse from sugar industry.

\subsubsection{Rice straw, paddy husk and coconut shells}

Sri Lanka has about 800,000 ha under paddy cultivation and the collective annual paddy production is about $4 \times 10^{6}$ MT in both Yala (southwest monsoon period) and Maha (northeast monsoon period) seasons. A considerable amount of rice straw is available after rice harvesting and most of it is put back to the rice fields as a soil conditioner and organic fertilizer. Therefore, rice straw is not available in sufficient quantities for power generation. Every metric ton of paddy would produce around $200 \mathrm{~kg}$ of paddy husk and annual production of paddy husk is about 800,000 MT. Though this 
is a sizable quantity, the surplus is rather small as it is already being used in the rice industry for parboiling of rice and in other traditional industries as a source of fuel. Problems associated with the collection and transportation of surplus paddy husk further constrains the use of this material in commercial scale power generation.

Annual production of coconut is around 2.8 billion nuts and a large quantity of coconut shells is produced as a byproduct. As in case of paddy husk, coconut shells are also used as a fuel in traditional industries and small quantity in electricity generation and active carbon production. As such significant quantities are not available for biomass based power generation in commercial scale.

\subsubsection{Energy Plantations}

Energy plantations are one of the main sources of biomass for power generation and Sri Lanka has a great potential for producing biomass using this source. There are four basic classes of energy plantations with different plant species.

- Short rotation energy plantations or short rotation coppice (SRC)

- Grasses and non-woody energy plantations

- Agricultural energy plantations

- Aquatics or hydroponics crops

\section{Short rotation energy plantations}

Wood from trees has been used for biomass fuel over centuries and traditional forestry has been the primary source of wood. Traditional forestry, however, aims at producing sawlogs, pulp and other forest produce in longer rotations and does not suit for producing biomass for energy. Short rotation energy plantations or short rotation coppice (SRC), on the other hand, are managed to produce biomass for power generation in much shorter rotations. This is achieved by producing biomass capturing the highest mean annual growth increment of the tree species used. After the initial establishment of these plantations biomass are obtained through coppicing. The length of coppice rotation and the number of coppices before the next establishment depends on the species used, site conditions and cultural practices. The rotation age can vary from 1-5 years depending on the species.

The production capacity of energy plantations depends on the planted species, site conditions of available lands and subsequent cultural practices. There are many fast growing tree species in Sri Lanka suitable for a variety of site conditions. These species can be used to establish monoculture or mixed plantations under different management regimes to obtain the biomass needed for power generation.

Sri Lanka is primarily divided into three geographical regions namely the dry, intermediate and wet zones and sub-divided in to 24 agro-ecological zones based on the rainfall, topography and soils. Though the matching of species with sites needs to be done using standard procedures, the species listed in Table 1 can be considered as good candidates for three main climatic regions in the country for short rotation energy plantations. Even under rain-fed cultivation these species are capable of producing 10-15 dry tons of biomass per hectare per annum and this can be improved significantly with improved management practices including irrigation and fertilization. 
Table 1: Suitable species for energy plantations.

\begin{tabular}{ll}
\hline Climatic Zone & Suitable Species \\
\hline Wet Zone & Gliricidia sepium \\
& Calliandra callothyrus \\
& Leucaena leucocephala \\
& Acacia mangium \\
& Eucalyptus robusta \\
& Gliricidia sepium \\
Intermediate Zone & Calliandra callothyrus \\
& Leucaena leucocephala \\
\hline Dry Zone & Gliricidia sepium \\
& Leucaena leucocephala \\
& Acacia auriculiformis \\
\hline
\end{tabular}

Among these species $G$. sepium has been identified as the most promising species for biomass production. Apart from wide growing range, easy establishment, ability to manage through coppicing for many years without re-establishment, ideal size of material and good quality of biomass are the desirable attributes of this species.

\section{Grasses and non-woody energy plantations}

Apart from trees, some grasses can also be used to produce biomass for energy. Rhizomatous grasses such as Miscanthus species are used in European countries for biomass production. This perennial grass is reported to be produced 14 dry tons of biomass per hectare per year which is comparable with the yield of short rotation energy plantations.

Illuk (Impereta cylindrica) and Mana (Cymbonogon spp.) are the wide spread natural grasses in Sri Lanka especially in the dry zone. Illuk, like Miscanthus, is a rhizomatous perennial grass but it is not capable of producing no more than 5 dry tons of biomass per hectare per year mainly due to the absence of a woody stem like in Miscanthus. Therefore, the use of locally available grasses for biomass production is not feasible in Sri Lanka.

\section{Agricultural energy plantations}

Many agricultural crops have the potential for use as energy crops. They can be used directly as biomass or to provide specific product for a given energy application. Sugar crops, starch crops and oil crops are the familiar agricultural crops having the potential for energy applications. There is a very limited potential in Sri Lanka to get materials from these sources for biomass energy production. Bagasse from sugar cane is used to generate part of the electricity needed for sugar industry. The potential of using oil crops such as Jatropa to produce bio diesel has been studied but the feasibility for commercial applications is yet to be proven.

Agricultural residues such as straw and husks and animal residues such as poultry litter have the potential to be used as raw materials for power generation. These materials are not available in sufficient quantities in Sri Lanka to be used in commercial energy applications and they already have more attractive alternate uses. 


\section{Lands}

Development of energy plantations perhaps is the best option for Sri Lanka to obtain biomass in quantities required for commercial scale power generation. In biomass based electricity generation 1 MW plant would need an extent of 500-1000 ha of lands to produce required biomass fuel depending on the species used, cultural practices and the land quality. Therefore, the land, both the availability and quality, perhaps is the single most important factor in developing commercial scale energy plantations.

\subsection{Availability}

The biomass based power generation and its favorable impact on the environment, especially on climate change mitigation, depend on the availability of lands to set up energy plantations for supplying biomass required for power plants. The total land area of Sri Lanka, estimated at 6.5 million hectares, can be categorised into urban, agricultural, crop, forest, range, wet, water and barren land.

Table 2: Land use in Sri Lanka.

\begin{tabular}{|c|c|c|}
\hline Land use type & Description & Extent (ha) \\
\hline \multirow[t]{6}{*}{ Urban Land } & Built-up land & 22,640 \\
\hline & Associated non-agricultural land & 7,319 \\
\hline & Homestead & 858,000 \\
\hline & Tree \& Other Perennial Crops & \\
\hline & Tea & 221,969 \\
\hline & Rubber & 127,000 \\
\hline \multirow[t]{6}{*}{ Agricultural land } & Coconut & 394,836 \\
\hline & Cinnamon & 8,880 \\
\hline & Cashew & 580 \\
\hline & Oil palm & 1,070 \\
\hline & Other perennial crops & 54,740 \\
\hline & Paddy & 525,338 \\
\hline \multirow[t]{3}{*}{ Crop land } & Sparsely used cropland & $1,119,665$ \\
\hline & Other crop land & 568,232 \\
\hline & Natural Forest & \\
\hline \multirow[t]{3}{*}{ Forest land } & Dense forest & $1,438,275$ \\
\hline & Open forest & 429,485 \\
\hline & Forest Plantations (productive) & 72,300 \\
\hline \multirow[t]{3}{*}{ Range Land } & Scrub land & 205,630 \\
\hline & Grass land & 105,000 \\
\hline & Forested & \\
\hline \multirow[t]{3}{*}{ Wet land } & Mangroves & 15,150 \\
\hline & Non forested & \\
\hline & Marsh & 42,400 \\
\hline Water & & 290,520 \\
\hline \multirow[t]{2}{*}{ Barren land } & & 77,480 \\
\hline & TOTAL & $6,586,509$ \\
\hline
\end{tabular}

Source: Department of Census \& Statistics and Forest Department (2012). 
Homegardens and tree and other perennial crops are the main land use types in agricultural lands while the crop lands include paddy and other annual crops along with a category called sparsely used croplands which accounts for more than one million hectares (Table 2). Though in many instances the lands under this category have been identified as the potential lands for energy plantation development, there are some practical problems associated with this category of lands. The total extent of this category has apparently been derived by subtracting the known extents of agricultural land uses from the total area of agricultural lands. As such it is very difficult to verify the exact locations and ownership of these lands without extensive ground checking. This category may include some of the areas currently under shifting cultivation and some lands in the forestry sector and estate sector. There is also a possibility to categorise some of the natural ecosystems currently under the protected area network as sparsely used crop lands or barren lands as the boundaries of some of the protected areas are yet be defined. Therefore, without a more detailed assessment with ground verification it is difficult to know the exact land extent under the categories of sparsely used crop lands and barren lands.

According to the latest forest cover assessment (2010) there are about 430,000 ha or $7 \%$ of the land area of the country under the category of 'sparse and open forests' which include tropical thorn forests, natural grasslands, savannah forests and scrub lands. There are instances this category of lands has been misinterpreted as degraded lands, may be due to the physical appearance, and has cited as lands available for other development works including growing fuel wood. These are actually naturally occurring vegetation types of the country and should not be used for any other purposes. Some of the forest areas, especially in the dry zone, which have been degraded due to shifting cultivation in the past, have been allowed to regenerate naturally to restore the forest cover while providing much needed habitat for wild elephants.

Under these circumstances a better idea about the potential lands for energy plantations could be obtained by examining the major land uses under state and private ownerships.

\subsubsection{State Lands}

Majority of state lands is managed by few state agencies namely Forest Department (FD), Department of Wildlife Conservation (DWLC), Mahaweli Authority of Sri Lanka, Land Reform Commission (LRC), Privatized Planation Companies, Janatha Estate Development Board (JEDB) and Sri Lanka State Plantation Corporation (SLSPC)

Nearly $30 \%$ of the total land area of the country amounting to 2 million hectares is under natural forest cover and managed by the FD and DWLC solely for the conservation of soil, water and biodiversity in order to sustain essential environmental services. As such these lands are not available for any other development projects.

A large extent of agricultural lands situated in their command areas is administered by the Mahaweli Authority of Sri Lanka and there may be a possibility of obtaining some of these lands for establishing dedicated energy plantations or for mix cropping with other agricultural crops. Detailed assessment is needed to identify the exact extents available under different land use types.

LRC manages a considerable extent of lands under different land uses and some of these lands are being leased out for various projects including agricultural projects. There may be a possibility of using some of these lands for energy plantation development. 


\subsubsection{Privately owned and lease hold lands}

There is a significant extent of marginal lands in tea and rubber plantations currently managed under lease agreements by the privatized plantation companies and JEDB and SLSPC. Some of these lands are being used for forestry and agricultural projects. These estates have the potential of diversifying their operations to produce biomass based electricity on commercial scale as they have the lands, adequate labor, and enough experience in managing short rotation fuel wood plantations.

Homegardens provide the biggest, and perhaps the best, source of privately owned lands for energy plantations. There are about 900,000 ha of homegardens in the country which accounts for nearly $15 \%$ of the total land area. Average size of a home garden is ranging from 0.4 ha in the wet zone to 0.8 ha in the dry zone. These lands are used for traditional home garden cropping and some spaces are still available for growing suitable energy crops. With right species and appropriate cropping patterns these lands can be used under out grower system to produce biomass for electricity generation.

There are about 395,000 ha of coconut plantations in Sri Lanka and these plantations can be used to under plant energy crops during the early stage (up to 8 years) and latter part (after 25 years) of the coconut plantation cycle without jeopardizing the coconut yield. If uniform age class distribution is assumed there are about 250,000 ha, of coconut plantations suitable for under planting energy crops.

There is a large extent of lands, especially in the dry zone, under shifting (chena) cultivation. Though the ownership of lands remains with the state, local people have been engaged in shifting cultivation in these lands for a long period of time. Most of these cultivations are seasonal and coincide with the North-East monsoon. Energy crops can be incorporated in to the existing chena cultivation under conservation farming systems, especially using alley cropping, where agricultural crops are grown in between the rows of energy crops. As most of the species used for energy plantations in Sri Lanka are legumes they can improve the soil fertility of shifting cultivation lands which are generally very poor in soil nutrients. Though the cultivation of agricultural crops in shifting cultivation areas is taking place only during the North East monsoon, the energy crops can be maintained throughout the year to produce biomass for power generation which will be an additional source of income for local farmers.

\subsection{Land value}

Post war development has created a big demand for available lands for commercial agriculture. Many lands referred to as marginal and barren lands, especially in the dry zone, are currently in high demand for the development of commercial crops. State lands used for shifting cultivation in the dry zone districts are being used for rubber and sugar cane cultivation through state sponsored programs. There is also an increasing demand for lands from the private sector for the development of commercial agriculture crops such as mango and banana. As such the opportunity cost of these lands has been increased considerably during past few years.

\section{Biomass Production}

As discussed earlier in this paper, energy plantations are one of the main sources of producing biomass. These plantations can be managed either as large scale dedicated plantations or as small scale plantations under out grower systems. 


\subsection{Dedicated energy plantations}

In the absence of a reliable forest based supply chain or agricultural feedstock chain to obtain biomass as a byproduct or residuals, short rotation energy plantations seems to be the only viable option for producing materials required for commercial scale biomass based power generation in Sri Lanka. These plantations, especially the dedicated plantations, have the advantage of stability of supply, producing the best quality biomass and increased efficiency in harvesting and processing. At present there is no significant extent of dedicated energy plantations managed for biomass production in Sri Lanka.

\subsection{Out-grower systems}

Out-grower systems are capable of using the unutilised and under-utilised resources for the production of biomass without placing too much burden on the existing farming systems. This system can provide much needed lands for energy crops and utilise part of idling labor for the production. This can be seen as a win-win situation as energy plantations are capable of generating additional income without jeopardising the production potential of main crop. However, the maintaining the stability of supply, quality of biomass, and harvesting and processing can be more challenging compared to the dedicated plantation management as a diverse group of people with changing priorities is involved in the production process. Cost of production can vary from site to site due to the prevailing socio economic conditions and efficiency of overall management.

As described in section 3.1.2, homegardens, coconut plantations and shifting cultivation areas can be used to produce biomass under out-grower systems with suitable tree species and appropriate cropping models. Properly implemented out-grower system would be more appealing due to the added environmental and socio-economic benefits.

\section{Power Generation Options}

Purpose-grown biomass either in dedicated plantations or through the out-grower systems can be used for power generation in three general applications.

- Stand-alone, grid-connected biomass-based power plants using plantation grown fuel

- Cogeneration at other existing facilities such as sugar mills and tea factories for on-site heat and power needs with export of excess power to the national grid using a combination of mill wastes (bagasse, wood waste) and plantation-grown biomass

- Co-firing at coal -fired electric generation facilities.

There are only limited experiences in operating stand-alone biomass based power plants in Sri Lanka and all aspects of biomass power generation from supply chain to technological options need to be thoroughly studied prior to make substantial investment on this sector.

There is, however, a very good potential for cogeneration in other existing facilities especially in tea factories in estate sector. Some of these factories already generate heat and electricity for their own use using fuel wood. Many estates are in the process of diversification of their operations and biomass based commercial electricity generation could be one of the viable options. Some of these estates have marginal lands that could be used for energy plantations and required labour is also available within the existing labor force. They also have the experience in fuel wood plantation management and biomass based power generation which is an added advantage. 
The third option above, co-firing at coal fired electric generation facilities, would need much more research prior to commence the commercial scale production.

\section{Technological Options}

The technological options available for biomass based power generation can be broadly categorised into two groups, conventional steam cycle based plants and those based on wood gasification technology.

The direct combustion systems involving conventional steam cycle is found to be cheaper in capital cost though the operating efficiencies tend to be around 20\%. This established technology is suitable for generation plants with capacities ranging from $1 \mathrm{MW}$ to as high as $50 \mathrm{MW}$. This may be the most suitable option for Sri Lankan conditions. The other advanced technologies involve the different wood gasification techniques depending on the scale of capacities.

\section{Economics of Plantation-grown Fuels for Power Generation}

Feasibility studies carried out in Sri Lanka as well as in some other countries have shown that plantation-grown biomass to produce electricity can be financially viable provided that local resource conditions are favorable and that the cost of conventional power supplies is expensive. In Sri Lankan conditions biomass based electricity has to compete with the already established hydro and coal power generation. Therefore, in order to improve the competitiveness of plantation-grown fuels for power generation would require:

- Lower cost and sustainable biomass production systems,

- More efficient and lower capital cost conversion technologies at scales appropriate for biomass energy applications.

The land base and the quality of sites is the key to produce low cost biomass especially in dedicated energy plantations. These two factors determine to a significant extent the degree of site preparation required, the choice of species, spacing, rotation age, required cultural management and soil amendments (fertilization, weed control, animal control, and pest management) and fuel transport and logistics. Land and site quality also defines biomass productivity, the major determinant of total feedstock cost. Productivity is also a key factor in determining the total size of the plantation, annual feedstock production, and the size of the conversion facility that can be supported.

The lands available for dedicated plantations in Sri Lanka include abandoned shifting cultivation (chena) lands and marginal lands with some physical limitations such as poor soils, low rainfall and lack of irrigation facilities. These lands are small in size and scattered which make commercial energy plantation development more expensive. The biomass production capacity of these lands is likely to be lower without added inputs such as irrigation facilities and fertilizer. Under these conditions opportunity cost of lands or land rent need to be significantly low to warrant investments on energy plantations.

The lands available for out-grower systems such as homegardens, coconut plantations and other small sized private lands have a comparatively higher biomass production capacity. However, the 
development of a system to utilise these lands for biomass production with numerous suppliers is going to be a challenge.

\section{Information Gaps}

Not having reliable information on land base and especially with regard to the production capacities of different species under different climatic conditions has been a problem for prospective investors for some time. Land issues are generally complex and the information available on suitable lands for biomass production is insufficient to make commercial investment decisions. Therefore, a systematic collection of land data with ground verification is needed to facilitate the investment on biomass based electricity generation.

Biomass production capacities of plant species varies with the site conditions and subsequent cultural practices. Much of the information currently used with regard to the biomass production potential is based on small plot data obtained under more favorable conditions. Real world conditions, however, are much different in terms of scale of operation and quality of available sites. Therefore, available species need to be tested in different agro ecological regions with most suitable cultural practices along with an economic analysis to obtain reliable information that can be used in the decision making process.

\section{Case studies}

Case studies are needed prior to getting in to the commercial scale biomass electricity generation as the available experiences are somewhat limited. Supply chain options and power generation options can be tested in the field in pilot sites. These studies can be designed to look in to technical, socio economic and managerial aspects.

The production potential of biomass using promising species in dedicated plantations, shifting cultivation areas as mixed cropping, home gardens, estate sector and in permanent crops such as coconut plantations can be verified through case studies. These studies need to be designed to examine the aspects of planting, subsequent management, harvesting, transport, post-harvest processing, and storage facilities. Different models can be tested in the field to identify the most suitable ones for a given site.

Power generation models can be tested separately or in conjunction with the biomass production to assess the efficiency, suitability and scale of operations.

\section{Conclusion}

There is a very high potential for developing biomass based electricity projects in Sri Lanka because it has an excellent growing conditions and a variety of tree species are available for energy plantation development to obtain required biomass for power generation. Suitable lands are available for biomass production both in state and private sectors but not having a comprehensive land database has been a problem to secure these lands. A variety of power generation and technological options is also available within the country and this could be fine-tuned through further research and case studies. An appropriate mechanism is needed to capture the full environmental and economic benefits of climate change mitigation and potential carbon trade benefits associated with biomass based power generation if this form of power generation to be competitive especially in the face of falling oil prices. 


\section{References}

Ariyadasa, K.P. 1996. Sri Lanka profile; In Asia Pacific agroforestry profiles (2 ${ }^{\text {nd }}$ ed). APAN Field Document No. 4 and RAP Publication 1996/20. Asia Pacific Agroforestry Network, Bogor, Indonesia and Food and Agriculture Organization of the United Nations, Bangkok, Thailand.

Ariyadasa, K.P. 2002. Assessment of tree resources in the homegardens of Sri Lanka. EC-FAO Partnership Program. Food and Agriculture Organization of the United Nations, Regional Office for Asia and the Pacific (RAP), Bangkok 10200, Thailand.

Ariyadasa, K.P. and Fedrick, D.J. 1987. Above ground biomass estimation for seven tree species grown on the coastal plains of Georgia. North Carolina State University, Raleigh, North Carolina.

Daranagama, U., Wijayatunga, P. and Ariyadasa, K.P. 1998. Feasibility of dendro-power based electricity generation in Sri Lanka. Research Report, Energy Forum, Sri Lanka.

Edirisinghe, E.A.P.N., Ariyadasa, K.P. and Chandani, R.P.D.S. 2012. Forest cover assessment in Sri Lanka. The Sri Lanka Forester, 34: 1-12.

Jewell, N. 1995. The use of Landsat TM data for estimating the area of home gardens. The Sri Lanka Forester. 20 (3,4): 79-86.

Statistical Pocket Book, 2012. Department of Census \& Statistics, Ministry of Finance and Planning, Colombo, Sri Lanka.

Wijayatunga, P., Daranagama, U. and Ariyadasa, K.P. 2005. Techno-economic feasibility of biomassbased electricity generation in Sri Lanka. Bioenergy: Realizing the Potential. Elsevier Inc. USA. 